\title{
Bacteriological Biodiversity and its Relationship with the Quality of Water in Panvel Lakes (Vishrale, Krishnale and Dewale Lake) at Raigad (Maharashtra), India
}

\author{
Prajapati Shashikala R. S. ${ }^{*}$ and Jadhav Anita S. ${ }^{2}$ \\ ${ }^{1}$ KLE Society's Science and Commerce College, Sector 1, Kalamboli, Panvel, Navi Mumbai, Maharashtra 410218, \\ India \\ 2 ICLES`MJ College of Arts, Science and Commerce, 53, Sector 9A, Vashi, Navi Mumbai 400 706, India \\ ${ }^{*}$ Corresponding Author
}

Received: $27^{\text {th }}$ April, 2021

Accepted: $29^{\text {th }}$ May, 2021

Published online: $2^{\text {nd }}$ June, 2021

https://doi.org/10.33745/ijzi.2021.v07i01.021

\begin{abstract}
This research is carried out to study the bacteriological biodiversity and quality of water during premonsoon, monsoon and post-monsoon in Panvel lakes, Maharashtra, India. Most Probable Number (MPN) count was carried out by using Mac Conkey's broth in order to classify the lakes into different categories. Pathogenic bacteria colonies were isolated from water samples collected from different lakes, by spread plate method. After incubation, different colonies from incubated plates were picked; purified by repeated sub-culturing before being examined for gram reaction, microscopically bacteria were identified into positive or negative, cocci or bacilli, rod or spiral. Biochemical analysis was carried out using different tests. The results were analyzed using Bergey's manual of systematic bacteriology. Many different types of bacteria were isolated from water samples that helped in classifying the lakes and knowing the bacterial loads of each lake.
\end{abstract}

Keywords: Bacteria, Biochemical test, MPN count, Lake, Panvel

Citation: Prajapati Shashikala R.S. and Jadhav Anita S.: Bacteriological biodiversity and its relationship with the quality of water in Panvel Lakes (Vishrale, Krishnale and Dewale Lake) at Raigad (Maharashtra), India. Intern. J. Zool. Invest. 7 (1): 266-271, 2021. https://doi.org/10.33745/ijzi.2021.v07i01.021

\section{Introduction}

Water is the basic requirement of all living organisms. It receives microorganisms from air, sewage, soil and other organic wastes. Many people in the world suffer from water borne diseases as contaminated water causes direct danger to health. Manja and Kaul (1992) stated that in developing countries like India, about 50 per cent of the deaths among 
the children are due to unhygienic and water born diseases. Hence, issues related to polluted water must be recognized as early as possible so that steps should be taken to treat the water (Anonymous, 1992). Lots of researches were performed on bacterial community throughout the world of the freshwater lakes like Lake Baikal, Russia (Khakhinov et al., 2012), Dianchi Lake, China (Bai et al., 2012), Chandra Tal, India (Yadav et al., 2016) and Dashair Lake, India (Yadav et al., 2017).

Bacteriological water analysis is a method of analyzing water to estimate the number of bacteria present and find out what sort of bacteria they are, and draw inference about the suitability of the water. Thus, present study was aimed to investigate the quality of water and presence of pathogenic and disease causing indicator organism in the lakes of Panvel city which may be pathogenic to human life. Analysis is usually performed using culture, biochemical and sometimes optical method.

\section{Materials and Methods}

\section{Sampling for Bacteriological Analysis:}

Water samples (during pre-monsoon, monsoon and post-monsoon) of three different lakes Vishrale, Krishnale and Dewale were collected in sterile leak proof glass bottle following the standard method of water collection for microbiological analysis.

\section{Culture Media:}

All the chemicals used were of analytical grade. Composition of nutrient Agar ( $\mathrm{pH} 7)$ for $100 \mathrm{ml}$ are: Peptone $1 \mathrm{~g}, \mathrm{NaCl} 0.5 \mathrm{~g}$, Meat Extract 0.3 g, DW $100 \mathrm{ml}$, Agar $3 \mathrm{~g}$.

\section{Biochemical Test:}

MPN count was carried out by using Mac Conkey's broth. Results obtained were compared with the standard chart and recorded as total MPN/100 ml. Escherichia coli were estimated by pour plate technique on MacConkey Agar incubated at 37 C (APHA, 2005).

Pathogenic bacterial colonies were isolated from water samples collected from different lakes, by spread plate method. After incubation, different colonies from incubated plates were picked; purified by repeated subculturing before being examined for gram reaction, microscopically bacteria were identified into positive or negative, cocci or bacilli, rod or spiral (Claus, 1992). Biochemical analysis included -- Sugar fermentation test, Methyl red test, VogesProskauer test, Citrate utilization test, Indole test, Urease test, Catalase test, Oxidase test, Gelatinase test, Triple Sugar Iron agar, lysine decarboxylase test, Orinithine test and $\mathrm{H}_{2} \mathrm{~S}$ production. The results were analyzed using Bergey's manual of systematic bacteriology (Sneath et al., 1986).

\section{Results and Discussion}

Seasonal variation in MPN count in the three lakes is represented in Tables 1-3 and Fig. 1. During monsoon season more MPN count is observed as 540/100 ml, 220/100 ml and $170 / 100 \mathrm{ml}$ in Vishrale, Krishnale and Dewale Lake, respectively. Bright pink colonies on incubated MacConkey plates were recognized as Escherichia coli (Harrigan and McCance, 1976).

The bacteria which were isolated from water samples include Escherichia coli, 
Table 1: Seasonal MPN index and 95\% confidence limits for Vishrale lake during 2010 - 2011

\begin{tabular}{|c|c|c|c|c|}
\hline \multirow{2}{*}{ Seasons } & Combination of positives & MPN index/100 ml & \multicolumn{2}{|c|}{ Confidence limits } \\
\cline { 3 - 5 } & & & Low & High \\
\hline Pre - monsoon & $5-5-1$ & 350 & 100 & 1100 \\
\hline Monsoon & $5-5-2$ & 540 & 150 & 1700 \\
\hline Post - monsoon & $5-4-3$ & 280 & 100 & 710 \\
\hline
\end{tabular}

Table 2: Seasonal MPN index and 95\% confidence limits for Krishnale lake during 2010 - 2011

\begin{tabular}{|c|c|c|c|c|}
\hline \multirow{2}{*}{ Seasons } & Combination of positives & MPN index/100 ml & \multicolumn{2}{|c|}{ Confidence limits } \\
\cline { 3 - 5 } & & & Low & High \\
\hline Pre - monsoon & $5-3-3$ & 170 & 70 & 400 \\
\hline Monsoon & $5-4-2$ & 220 & 70 & 440 \\
\hline Post - monsoon & $5-4-0$ & 130 & 36 & 400 \\
\hline
\end{tabular}

Table 3: Seasonal MPN index and 95\% confidence limits for Dewale lake during 2010 - 2011

\begin{tabular}{|c|c|c|c|c|}
\hline \multirow{2}{*}{ Seasons } & Combination of positives & MPN index/100 ml & \multicolumn{2}{|c|}{ Confidence limits } \\
\cline { 3 - 5 } & & & Low & High \\
\hline Pre - monsoon & $5-3-2$ & 140 & 52 & 400 \\
\hline Monsoon & $5-3-3$ & 170 & 70 & 400 \\
\hline Post - monsoon & $5-4-0$ & 130 & 36 & 400 \\
\hline
\end{tabular}

Staphylococcus aureus, Klebsiella sp., Proteus sp., Salmonella sp., Shigella sp., Vibreo cholerae, Pseudomonas aeruginosa, Enterobacter sp. and Bacillus sp. Staphylococcus 
Table 4: List of isolated micro-organisms from the three lakes

\begin{tabular}{|c|c|}
\hline Isolates & Description of isolates \\
\hline Bacillus & $\begin{array}{l}\text { Gram positive, spore forming rods, Catalase positive, creamy colony on } \\
\text { Nutrient Agar }\end{array}$ \\
\hline Escherichia coli & $\begin{array}{l}\text { Gram negative rod, heavy lactose fermenter, does not utilize citrate, } \\
\text { indole positive test, ferments mannitol, pinkish colony }\end{array}$ \\
\hline Salmonella & $\begin{array}{l}\text { Dark centered gram negative, Non-lactose fermenting, urease } \\
\text { negative, utilize citrate, produces } \mathrm{H}_{2} \mathrm{~S}\end{array}$ \\
\hline Enterobacter & Gram negative rod, lactose fermenting, utilize citrate \\
\hline Shigella & Non-lactose fermenting, does not utilize citrate, produces $\mathrm{H}_{2} \mathrm{~S}$ \\
\hline S. aureus & $\begin{array}{l}\text { Opaque, golden yellow colony on nutrient agar, Gram positive cocci, } \\
\text { Catalase positive, mannitol fermenter }\end{array}$ \\
\hline Pseudomonas aeruginosa & $\begin{array}{l}\text { Colourless colony on Nutrient Agar, Gram negative rod, Catalase } \\
\text { positive, negative lactose fermentation, positive H2S production, } \\
\text { positive Oxidase }\end{array}$ \\
\hline Vibreo cholerae & Gram negative rod, Oxidase positive, glucose fermenter \\
\hline Klebsiella & $\begin{array}{c}\text { Gram negative rod, Oxidase negative, indole negative, MR negative, VP } \\
\text { positive, lysine positive }\end{array}$ \\
\hline Proteus & $\begin{array}{l}\text { Translucent colony with serrated margins, Gram negative, glucose } \\
\text { positive, Gelatinase positive }\end{array}$ \\
\hline
\end{tabular}

aureus and Bacillus species are gram positive and rest are gram negative bacteria. Characterization of bacteria is shown in Table 4.

Some degree of contamination is always present in surface water bodies due to animal and human activities that results in increased bacterial concentration of lake water. In the present study, maximum MPN count is revealed during monsoon and minimum during post-monsoon season. Similar observations were documented by Agarwal and Rajwar (2010) and Singh and Sharma (2016). Presence of coliform is the primary bacterial indicator for faecal pollution in water as they are unable to survive in clean water (Mishra et al., 2009). Based on studies it was confirmed that majority of the coliform bacteria were found to be gram negative. The highly polluted surface water is abundant in various types of bacteria.

Total bacterial load of Vishrale lake was higher than other lakes. With respect to water quality for the best use, we categorized the water body depending on the values of coliforms (Table 5). Thus, in the present investigation we can place Vishrale lake in III category as "Satisfactory", whereas Krishnale 
Lake and Dewale lake is categorized in II lakes can be used for the purpose of bathing category as "good". Thus the water of these and swimming (Pandey and Sharma, 1999).

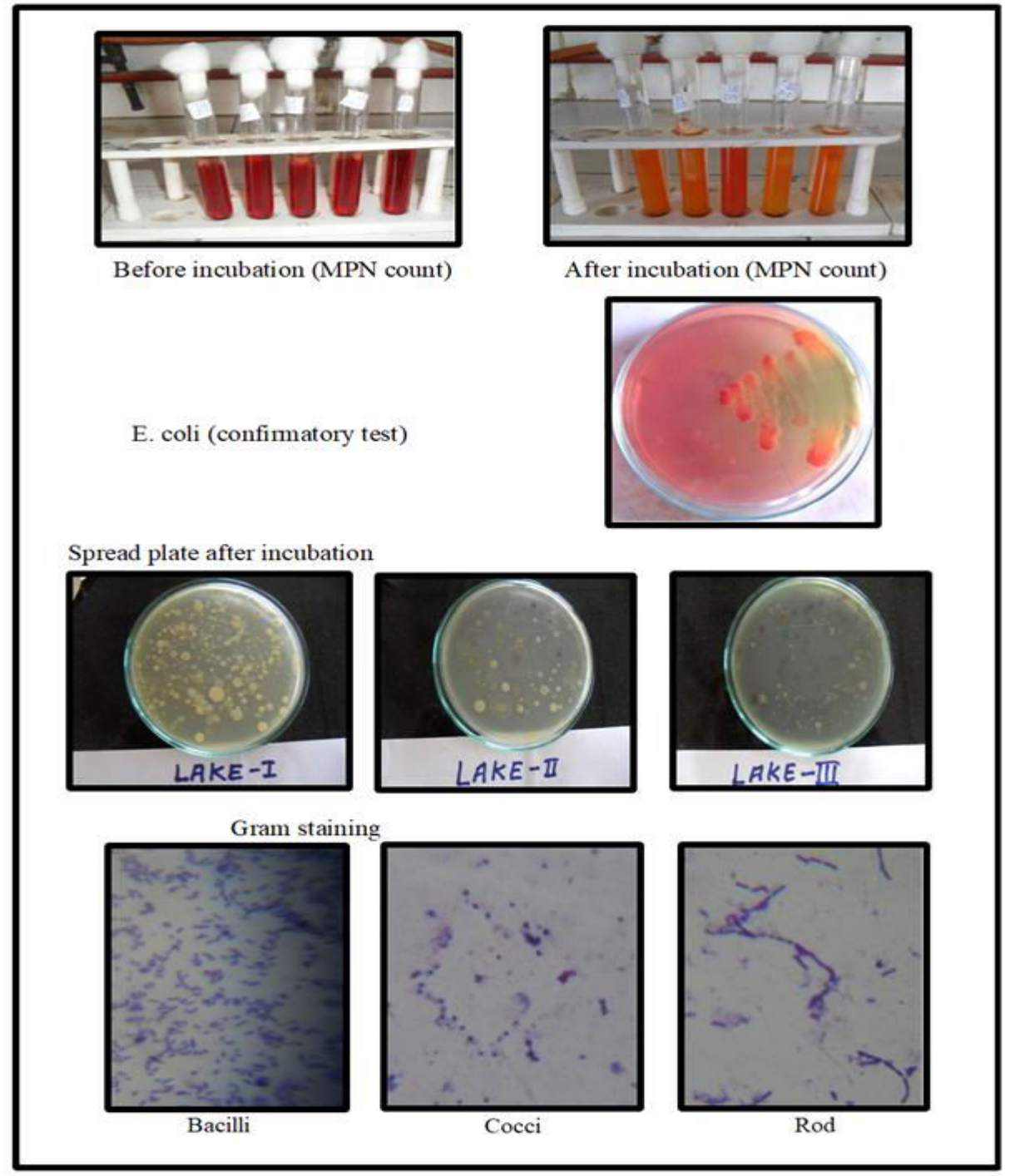

Fig. 1: MPN count

Table 5: Suggested values of Coliform/100 ml for beneficial uses of water (Pandey and Sharma, 1999)

\begin{tabular}{|c|c|c|c|c|}
\hline Sr. No. & Water Quality & Grade & Bathing \& Swimming & Public Water Supply \\
\hline 1. & Excellent & I & $<10$ & $<100$ \\
\hline 2. & Good & II & 4 & 200 \\
\hline 3. & Satisfactory & III & 250 & 800 \\
\hline 4. & Poor & IV & 1500 & 1000 \\
\hline 5. & Unacceptable & V & $>6000$ & $>8000$ \\
\hline
\end{tabular}




\section{References}

Agarwal AK and Rajwar GS. (2010) Physico-chemical and microbiological study of Tehri Dam Reservoir, Garhwal Himalaya, India. Jf Am Sci. 6(6): 65-71.

Anonymous (1992) Laboratory manual for the examination of water, wastewater and soil. $2^{\text {nd }}$ Ed. VCH Publisher Inc. NY (USA), pp, 135-136.

APHA (2005) Standard methods for the examination of waste and wastewater. $21^{\text {st }} \mathrm{Ed}$, Washington, DC 20001-3710.

Bai Y, Shi Q, Wen D, Li Z, Jefferson WA, Feng C and Tang $X$. (2012) Bacterial communities in the sediments of Dianchi Lake, a partitioned eutrophic waterbody in China. PLoS One 7: e37796. https://doi.org/ 10.1371/journal.pone.0037796.

Claus DC. (1992) A standardized gram staining procedure. World J Microbiol Biotechnol. 8: 451-452.

Harrigan WF and McCance (1976): Laboratory methods in food and diary microbiology. Academic Press, London, UK, pp. 452.

Khakhinov V, Namsaraev B, Dorzhieva GS and Buryukhaev S. (2012) Hydrochemical and microbiological characteristics of bog ecosystems on the isthmus of Svyatoi Nos Peninsula (Lake Baikal). Geo Nat Resour. 33: 298-303.
Manja SK and Kaul RK. (1992) Efficacy of a simple test for bacteriological quality of water. J Ind Assoc Environ Managem. 19: 18-20.

Mishra A, Mukherjee A and Tripathi BD. (2009) Seasonal and temporal variations in physico chemical and bacteriological characteristics of river Ganga in Varanasi. Int J Environ Res. 3(3): 395-402.

Pandey KS and Sharma SD. (1999) Studies on water quality index for Ramganga River at Moradabad, Uttar Pradesh. Poll Res. 18(3): 327-333.

Singh Brij M and Sharma RC. (2016) Studies of physicochemical and bacteriological characteristics of Jaisamand Lake, Alwar (RAJ.). IOSR J Environ Sci Toxicol Food Technol. 10: 1-9.

Sneath PHA, Mair NS, Sharpe ME and Holt JG. (1986) Bergey's Manual of Systemic Bacteriology Vol. 2. Williams and Wilkins Co. Baltimore.

Yadav AN, Verma P, Sachan SG.and Saxena AK. (2017) Biodiversity and biotechnological applications of psychrotrophic microbes isolated from Indian Himalayan regions. EC Microbiol ECO 1: 48-54. 